\title{
Peran Mahasiswa Teologi UKIM dalam Program Taat Protokol Kesehatan 5M dan Vaksinasi di Jemaat GPM Rehoboth
}

\author{
Susi Rumthe, Hetreda Apalem, Lisela Rahadat, Jeanly Hukunala, Tasya Sinay, Vania Tanjaya, \\ Ensia Wasaleruai, Dave Stenly Nenkeula, \& Aleta Apriliana Ruimassa*
}

Universitas Kristen Indonesia Maluku, Indonesia

\begin{abstract}
Pandemi COVID-19 telah mewabah di dunia bahkan di Maluku terlebih khusus Jemaat GPM Rehoboth kurang lebih 1 tahun. Pandemi ini berdampak besar bagi berbagai aspek kehidupan warga jemaat. Namun banyak upaya yang sudah dilakukan oleh pemerintah, tenaga kesehatan maupun gereja dalam memutus mata rantai penyebaran COVID-19. Upaya yang dilakukan seperti peraturan untuk mematuhi Prokes 5M. Pada survey lapangan di sektor Sumber Kasih, Elefantin, Galilea dan Bethania ditemui bahwa masih kurangnya kesadaran warga jemaat untuk mematuhi Prokes 5M. Selain itu upaya yang juga dilakukan adalah melakukan program vaksinasi. Pada survey awal, melalui pembagian kuesioner di sektor Sumber Kasih Jemaat GPM Rehoboth, ditemukan bahwa masih minimnya pemahaman warga tentang manfaat dari vaksin. Hal tersebut dapat kita lihat dari hasil kuesioner pertama yang mengasilkan beberapa persoalan yang membuat warga jemaat masih takut untuk divaksin, di antaranya yatu: 1). Warga jemaat mempunyai penyakit bawaan, 2). Menganggap bahwa COVID-19 bukanlah masalah yang sulit sehingga merasa tidak membutuhkan vaksin, 3) Tidak yakin akan efektivitas vaksin COVID-19, 4). masih takut akan efek samping dari vaksin. 5). warga jemaat yang percaya akan isu tentang vaksin yang mengandung chip. Berdasarkan masalah yang ada, maka edukasi yang diimplementasikan dalam sektor Sumber Kasih adalah: 1). Melakukan sosialisasi vaksin melalui pengeras suara gereja, 2). Himbauan mengikuti vaksinasi melalui audio yang diputar sebelum kebaktian melalui pengeras suara gereja, 3). Melakukan sosialisasi lewat media luar ruangan tentang taat protokol kesehatan 5M. Seperti pemasangan spanduk taat protokol kesehatan 5M. Luaran kegiatan ini telah diupload pada channel YouTube https://youtu.be/R8i3W9G6INg.
\end{abstract}

Keywords: Edukasi; Taat Protokol Kesehatan 5M; Vaksinasi; Jemaat Rehoboth; COVID-19.

\section{Pendahuluan}

Kuliah Kerja Nyata (KKN) Universitas Kristen Indonesia Maluku (UKIM) pada masa pandemi diprogramkan untuk dilaksanakan pada kawasan tempat tinggal mahasiswa sehingga mempermudah pelaksanaan program kerja yang direncanakan serta mempermudah koordinasi dengan jemaat/masyarakat terkait. Mahasiswa juga didampingi secara online untuk bagaimana memprogramkan kegiatan-kegiatan serta menulis kronologis hasilnya berupa artikel hasil pengabdian masyarakat (Touwely, et.al., 2019). Jemaat GPM Rehoboth merupakan salah satu jemaat di Gereja Protestan Maluku (GPM), Klasis Pulau Ambon. Jemaat GPM termasuk dalam salah satu jemaat terbesar di GPM dengan memiliki 33 sektor pelayanan, 80 unit dengan 3019 kepala keluarga dan jumlah jiwa 12.479 jiwa (laki-laki: 6.273 jiwa dan perempuan 6.206 jiwa). Secara administratif wilayah pelayanan jemaat GPM Rehoboth terbentang dari pesisir tanah lapang kecil menuju daerah perbukitan gunung nona (Tim Renstra, 2021).

\footnotetext{
* Corresponding author:

E-mail address: aruimassa@gmail.com
} 
Dalam jemaat Rehoboth terdapat beberapa sektor yang menjadi lokus penelitian yaitu; sektor Sumber Kasih, sektor Elefantin, sektor Galilea, dan sektor Bethania. Sektor Sumber Kasih memiliki 2 unit pelayanan yang terdiri dari 36 KK di unit 1 dan 30 KK di unit 2, jadi total keseluruhan didalam sektor Sumber Kasih terdapat 66 KK. Sektor Galiela memiliki 3 unit pelayanan yang terdiri dari $38 \mathrm{KK}$ di unit 1,50 KK di unit 2, dan $62 \mathrm{KK}$ di unit 3 jadi total keseluruhan didalam sektor Galilea terdapat $150 \mathrm{KK}$. Sektor Elefantin memiliki 2 unit pelayanan yang terdiri dari $23 \mathrm{KK}$ di unit 1 dan 34 KK di unit 2, jadi total keseluruhan didalam sektor Elefantin terdapat 57 KK. Dan untuk sektor Bethania memiliki 2 unit pelayanan yang terdiri dari $57 \mathrm{KK}$ di unit 1 dan $47 \mathrm{KK}$ di unit 2, jadi total keseluruhan didalam sektor Bethania terdapat 104 KK (Tim Renstra, 2021)..

Dengan banyaknya jumlah jiwa yang ada di setiap sektor maka perlunya perlindungan dari berbagai interkasi yang terjadi pada masa pandemi COVID-19 ini. Perlindungan perlu dilakukan karena virus COVID-19 ini sangat mudah menular. Penularan melalui tetesan pernapasan dan kontak adalah rute utama. Virus ditularkan melalui tetesan yang dihasilkan ketika orang postif COVID-19 batuk, bersin atau berbicara, dan orang yang rentan dapat terinfeksi setelah menghirup tetesan (Safrizal, et.al., 2020).

Melalui para ahli (ahli virus) telah merumuskan tata cara prtokol kesehatan yang harus dilakukan selama masa pandemi COVID-19 yang disebut "Protokol Kesehatan 5 M". Progam taat dan displin Prokes 5M telah di sosialisasikan oleh pemerintah. Protokol Kesehatan 5M terdiri dari; 1) Memakai masker, menggunakan masker 2 lapis (lapis pertama masker medis dan lapis kedua masker kain) menutupi arena hidung dan mulut, 2) Menjaga Jarak minimal 2 M, 3)Mencuci tangan di air bersih yang mengalir dan menggunakan sabun, namun jika sedang berpergian maka bawa dan gunakan Hand Sanitaizer untuk mencuci tangan, 4) Menghindari Kerumunan, 5) Membatasi Mobilitas. Selain 5 hal ini upaya pencegahan dilakukan dengan mengikuti program vaksinasi COVID-19.

Vaksinasi adalah proses di dalam tubuh, dimana seseorang menjadi kebal atau terlindungi dari suatu penyakit sehingga apabila suatu terpajan dengan penyakit tersebut maka tidak akan sakit atau hanya mengalami sakit ringan, biasanya dengan pemberian vaksin. Vaksin adalah produk biologi yang berisi antigen berupa mikroorganisme atau bagiannya atau zat yang dihasilkannya yang telah diolah sedemikian rupa sehingga aman apabila diberikan kepada seseorang akan menimbulkan kekebalan secara aktif terhadap penyakit tetentu (Kementerian Kesehatan Republik Indonesia, 2021; Septiana, 2020; Tim Komunikasi Publik - KPCPEN, 2021).

Manfaat vaksin COVID-19 sangat baik, namun warga jemaat kurang teredukasi dan sosialisasi, sehingga banyak dari warga jemaat yang takut untuk divaksin. Pada survey awal, dengan pembagian kuesioner di Sektor Sumber Kasih ditemukan bahwa banya sekali pandangan-pandangan warga jemaat yang keliru tentang vaksin seperti; takut divaksin karena mempunyai penyakit bawaan, tidak percaya akan efektivitas vaksin, vaksin hanya menambah imun sehingga tidak terlalu penting, takut efek samping dari vaksin, dan lebih parah lagi percaya pada berita-berita yang tidak teruji kebenarannya yang tersebar di media sosial bahwa vaksin mengandung chip yang berkaitan dengan antikris (Winastya, 2021; Sembiring, 2021; Astutik, 2021).

Edukasi dan sosialisai akan disiplin Prokes 5M juga penting, karena dilihat dari hasil survey lapangan ditemukan bahwa di titik tertentu seperti sektor Galilea yang dekat pantai wainitu, Sektor Elefantin yang dekat pasar darurat, sektor Bethania yang dekat dengan tempat cuci mobil, seringkali banyak dikunjungi oleh warga jemaat bahkan orang-orang diluar jemaat yang tidak menggunakan masker. Melakukan interaksi dengan tidak mematuhi prokes 5M.

Berdasarkan pengamatan secara langsung maka permasalah mitra antara lain: (a) Kurangnya edukasi atau sosialisai tentang pentingnya pentingnya vaksinasi COVID-19 demi menekan layu penyebaran virus, (b) kurangnya kepedulian dari warga jemaat untuk mematuhi prokes 5M. Untuk itu kelompok Pengabdian Kepada Masyarakat Fakultas Teologi Ukim Kelompok 4 akan melakukan pendampingan warga Jemaat khususnya warga jemaat di Sektor Sumber Kasih, Elefantin, Galilea, dan Bethania menyangkut dengan disiplin Prokes 5M dan mengikuti program vaksinasi.

\section{Permasalahan Prioritas Mitra}

Berdasarkan analisis situasi, pengamatan secara langsaung maka permasalahan di Sektor Sumber Kasih, Galilea, dan Elefantin antara lain: 
a. Ada sebagaian yang belum melakukan vaksinasi karena banyaknya isu yang ada di masyarakat contonya seperti :

- Menaruh chip di dalam tubuh

- Takut jarum suntik

- Memiliki penyakit bawaan

- Khawatir dengan efek samping dan hanya menganggap vaksin untuk menambah sistem imun agar tidak lemah.

- Tidak percaya akan efektivitas vaksin

b. Jemaat Rehoboth di sektor Elefantin, sektor Galelia, dan Sektor Bethania belum memiliki kesadaran untuk melakukan Protokol kesehatan misalnya :

- Di Sektor Elefantin saat melakukan aktifitas di pasar atau sekitar pasar orang-orang tidak memakai masker dan selalu berkerumun.

- Di sektor Galelia tepatnya di dekat pantai orang-orang berkerumun dan tidak memakai masker serta tidak menjaga jarak

- Di Sektor Bethania orang-orang belum menjalankan protokol kesehatan dengan baik dan saat melakukan kegiatan di luar rumah tidak menggunakan Masker, serta berkerumun.

Setelah didiskusikan bersama mitra, maka akan dilakukan pendampingan kepada warga jemaat khususnya sektor sumber Kasih, Elefantin, Galilea dan Bethania menyangkut dengan pemahaman tentang pentingnya mematuhi Prokes $5 \mathrm{M}$ dan mengikuti vaksinasi demi menekan angka penyebaran virus COVID-19.

\section{Solusi Permasalahan}

Ada tiga persoalan mitra dari hasil penelitian lapangan dan penbagian kuesioner yang dilakukan yaitu:

a. Kurangnya pemahaman warga jemaat tentang vaksin dan juga taat prokes $5 \mathrm{M}$

b. Kurangnya kesadaran akan pentingnya perilaku disiplin 5M

c. Warga jemaat yang tidak mau vaksin akibat berbagai isu dan juga dampak vaksin yang beredar

Dari 3 masalah di atas maka perlu adanya solusi untuk menjawab semua permasalahan tersebut. Dan solusi yang di tawarkan atau di lakukan yaitu:

a. Bekerjasama dengan RT di sekitar Sektor Sumber Kasih, Sektor Elefantin Sektor Bethania dan Sektor Galilea

b. Bekerjasama dengan Majelis Jemaat GPM Rehoboth, Pendeta Jemaat Sumber Kasih.

c. Memberikan Sosialisasi tentang Protokol Kesehatan dan Vaksinasi

d. Membuat video taat Protokol Kesehatan dan membagikannya melalui media sosial

e. Membuat Audio suara kasih tentang taat Protokol Kesehatan 5M dan program vaksinasi yang diputar melalui toa gereja sebelum kebaktian

f. Pembuatan Spanduk di 4 titik Yaitu sektor Sumber kasih, sektor Elefantin, Sektor Galilea dan sektor Sinai

\section{Metode Pelaksanaan}

Langkah-langkah kegiatan PKM yang dilakukan ini diatur sebagai berikut:

\section{1) Tahap Observasi dan Analisis Kebutuhan}

Tahap ini bertujuan menggali informasi dalam rangka mendapatkan solusi permasalahan yang efektif dengan proses penyelesaian masalah yang efisien. Ada beberapa kegiatan yang dilaksanakan yaitu: Berdiskusi dengan pendeta jemaat dan Ketua RT yang ada di sektor Sumber Kasih, Elefantin, Bethania, dan Galilea untuk menggali informasi sebanyakbanyaknya terkait permasalahan yang ditemukan utuk diselesaikan. Setelah itu menganalisis solusi yang bisa dilakukan untuk menjawab masalah yang ada. 


\section{2) Tahap Pelaksanaan Edukasi Tentang Disiplin Prokes 5M dan Mengikuti Program Vaksinasi}

Tahap ini bertujuan memberikan pemahaman/pengetahuan kepada mitra terkait dengan pemahaman/pengetahuan tentang disiplin prokes $5 \mathrm{M}$ dan mengikuti vaksinasi. Tahap ini dilakukan dengan menggunakan media cetak, yaitu spanduk, media suara, sosialisasi melalui toa gereja dan suara kasih yang diputar sebelum kebaktian, dan media audio visual berupa video animasi disiplin prokes $5 \mathrm{M}$ dan mengikuti program vaksinasi. Partisipasi mitra dalam kegiatan ini adalah: menyiapkan waktu dan kesediannya untuk terlibat dalam pemasangan spanduk dan mendengar sosialisasi dari rumah masing-masing.

\section{3) Tahap Pengadaan Spanduk, Video dan Audio Himbauan serta Sosialisasi}

Tahap ini direncanakan agar masyarakat teredukasi dan lebih peduli serta taat dalam menjalankan protokol 5M serta memahami tentang pentingnya vaksin COVID-19. Spanduk yang dipasang dan video yang dibuat berkaitan dengan tata cara 5M yaitu: Memakai Masker, Mencuci tangan, Menjaga Jarak, Membatasi Mobilitas, dan Menghindari Kerumunan. Untuk himbauan berupa suara kasih dan sosialisasi yang bekerja sama dengan dinas kesehatan kota (Puskesmas Air Salobar) dilakukan melalui pengeras suara atau toa gereja.

\section{4) Tahap Evaluasi dan Tindak Lanjut}

Secara prinsip dalam pelaksanaan kegiatan tidak terlalu banyak hambatan. Hanya saja karena harus melakukan kegiatan dalam kondisi pandemi COVID-19 membuat tidak diperbolehkan untuk melibatkan banyak orang, proses edukasi hanya dilakukan searah dengan melibatkan tenaga medis, pendeta jemaat, MJ dam Koordinator unit. Sedangkan jemaat mendengar dari rumah masing-masinng. Selain itu waktu sosialisasi terlalu singkat hanya 30 menit mengingat masamasa pandemi yang membatasi. Kendala yang lain juga terletak pada pertemuan dengan RT yang beberapa kali harus tertunda karena kesibukan dari ketua RT.

\section{Hasil dan Luaran yang Dicapai}

Dari rencana kerja pelaksanaan yang telah dibuat dan disepakati dalam rapat kelompok bersama instruktur dan disetuji bersama dengan mitra, maka kegiatan terbagi dalam beberapa tahapan pelaksanaan sebagai berikut:

\section{1) Sosialisasi tentang Taat Protokol Kesehatan 5M dan Vaksinasi}

Pandemi COVID-19 yang mengakibatkan adanya batasan untuk tidak berkerumun, menjaga jarak, dan tidak boleh bertemu atau melakukan interaksi dengan banyak orang membuat sosialisasi harus dilakukan dengan media suara dalam hal ini sosialisasi menggunakan pengeras suara atau toa gereja. Sosialisasi yang dilakukan satu arah, hanya narasumber atau tenaga medis yang menjelaskan, dan sosialisasi dilakukan di Gereja Sumber Kasih. Untuk menjawab kegelisahan, ketidaktahuan warga jemaat yang ada di sektor Sumber tentang vaksin dan juga protokol kesehatan, maka sebelum sosialisasi dilakukan kelompok sudah membagikan kuesioner untuk melihat apa yang menjadi pertanyaan warga jemaat atau apa yang belum diketahui oleh warga jemaat tentang vaksin.

Pembagian Kuesioner dilakukan Senin 2 Agustus 2021, pada 66 KK di Sektor Sumber Kasih. Kuesioner yang dibagi sebanyak 150 lembar, dan hanya dibagikan kepada warga Jemaat yang berumur 18 ke atas. Kategori umur 18 tahun ke atas adalah kelompok warga jemaat yang banyak melakukan aktivitas diluar, baik itu bekerja ataupun melakukan aktivitas di luar lainnya, selain itu juga kelompok umur 18 ke atas adalah kelompok umur yang sudah bisa divaksin.

Dari hasil kuesioner, ditemukan bahwa masih banyak warga jemaat sudah bisa taat akan protokol kesehatan, namun saat keluar rumah belum banyak yang membawa Hand Sanitizer. Menjadi masalah yang krusial dari hasil kuesioner adalah vaksinasi. Dari 150 kuesioner yang dibagikan, ditemukan ada 12 orang yang sudah divaksin sedangkan 138 orang tidak mau divaksin karena beberapa alasan; 1) memiliki penyakit bawaan, 2) takut efek samping dari vaksin, 3) tidak percaya akan efektivitas vaksin, 4) percaya akan berita yang beredar bahwa vaksin mengandung chip yang berkaitan dengan antikris. 
Mencermati pemahaman warga jemaat yang masih keliru tentang protokol kesehatan dan vaksinasi, maka sosialisasi yang dilakukan bertemakan "Taat Protokol Kesehatan dan Pentingnya Vaksinasi". Sosialisasi ini dilakukan dengan bekerja sama dengan pihak kesehatan dari Puskemas Air Salobar. Kelompok memasukan surat di Puskesmas Air Salobar pada Jumat 6 Agustus 2021, dan hari itu juga surat diterima dan kelompok melakukan percakapan dengan dokter. Dari percakapan yang dibangum kelompok mencoba menyampaikan tema dari sosialisasi yang akan dilakukan dan berabgai pertanyaan warga jemaat dari hasil kuesioner. Hal ini dilakukan karena sosialisasi yang dilakukan satu arah sehingga tidak adanya percakapan atau pertanyaan dari warga jemaat, dari penjelasan tenaga medis bisa menjawab kegelisahan atau ketidaktauan warga jemaat yang ada di Kuesioner.

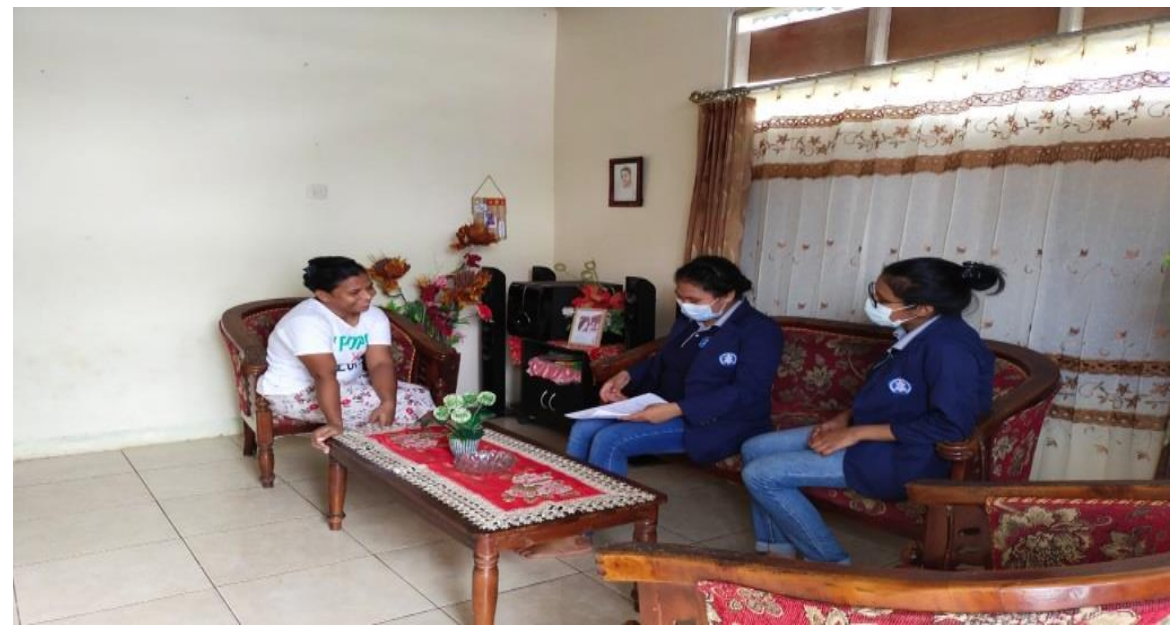

Gambar 1. Pembagian Kuesioner

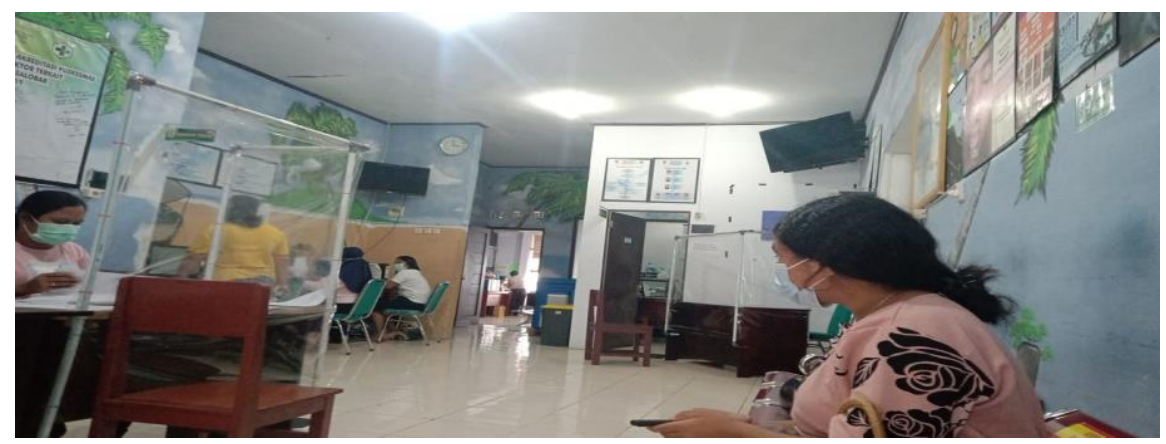

Gambar 2. Menemui Tenaga Medis

Setelah bertemu dengan dr. Sentya Akisan di Puskesmas Air Salobar, maka Dr. Sentya bersedia untuk menjadi narasumber. Sosialisasi dilakukan pada hari Selasa, 10 Agustus 2021, jam 14.00 WIT di gereja Sumber Kasih Farmasi. Namun sebelum sosialisasi dilakukan, majelis jemaat sudah memberitahukan warga jemaat yang ada di sektor Sumber Kasih ada sosialisasi jam 14.00 WIT melalui toa gereja, sehingga warga jemaat bisa dengar dari rumah masing-masing. Dalam sosialisasi yang dilakukan juga dihadiri oleh Pendeta Jemaat, ibu Pdt Lili Picanussa, dua majelis jemaat sektor Sumber kasih, 1 koordinator unit, 2 tuagama, dan 1 pemuda.

Materi sosialisasi berisi tentang disiplin protokol kesehatan yang bukan lagi 5M tetapi sudah $6 \mathrm{M}$ yaitu; 1) Memakai Masker, 2) Menjaga Jarak, 3) Menghindari Kerumunan, 4) Mencuci tangan dan memakai Hand Sanitizer saat melakukan aktivitas di luar rumah, 5) Membatasi mobilitas, dan 6) Menghindari makan bersama. Selain disiplin Prokes, sosialisasi tentang vaksin demi menjawab kegelisahan dan ketidaktauan warga jemaat tentang vaksinasi dijelaskan. 
Dengan adanya program ini warga jemaat Sumber Kasih memiliki pengetahuan yang lebih tentang disiplin prokes 5M dan juga teredukasi tentang manfaat vaksin.

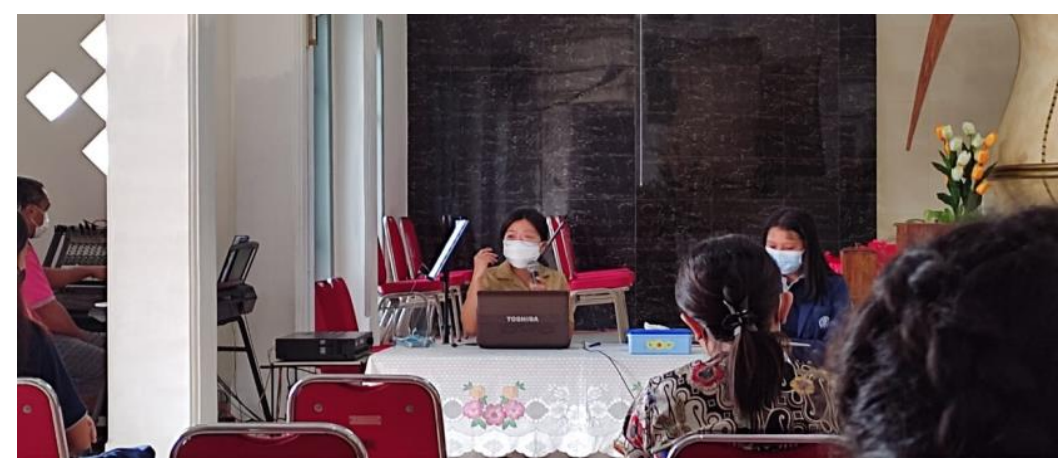

Gambar 3. Proses Sosialisasi

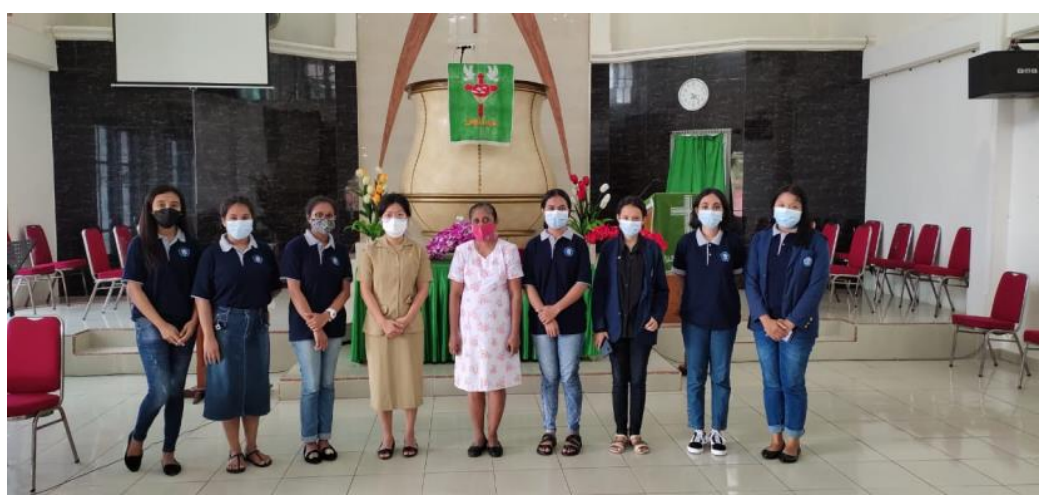

Gambar 4. Foto bersama Nakes dan Pendeta

Sosialisasi ini juga dilakukan di waktu yang tepat karena pada tanggal 12 Agustus 2021 ada dilakukan program vaksin di jemaat Rehoboth. Hasil dari sosialisaasi ini membuat warga jemaat lebih paham sebelum mengikuti program vaksinasi yang dilakukan oleh jemaat GPM Rehoboth yang bekerja sama dengan pihak Karumkit Bhayangkara kota Ambon, pada 12 Agustus 2021. Ada 50 orang dari sumber Kasih yang di vaksin. 35 orang dari unit 1 dan 15 orang dari unit 2.

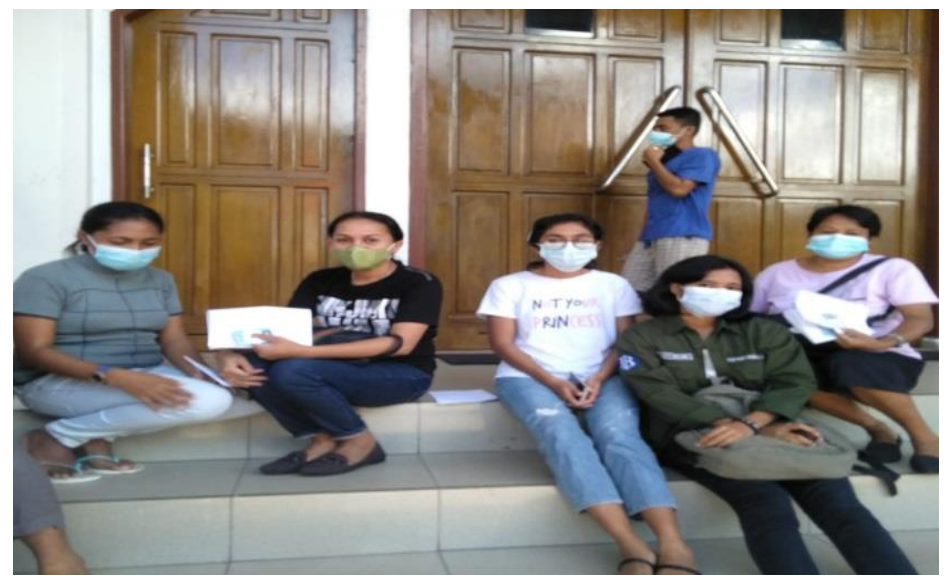


Gambar 5. Warga Jemaat yang mau divaksin dalam kegiatan vaksin massal di Gereja Rehoboth

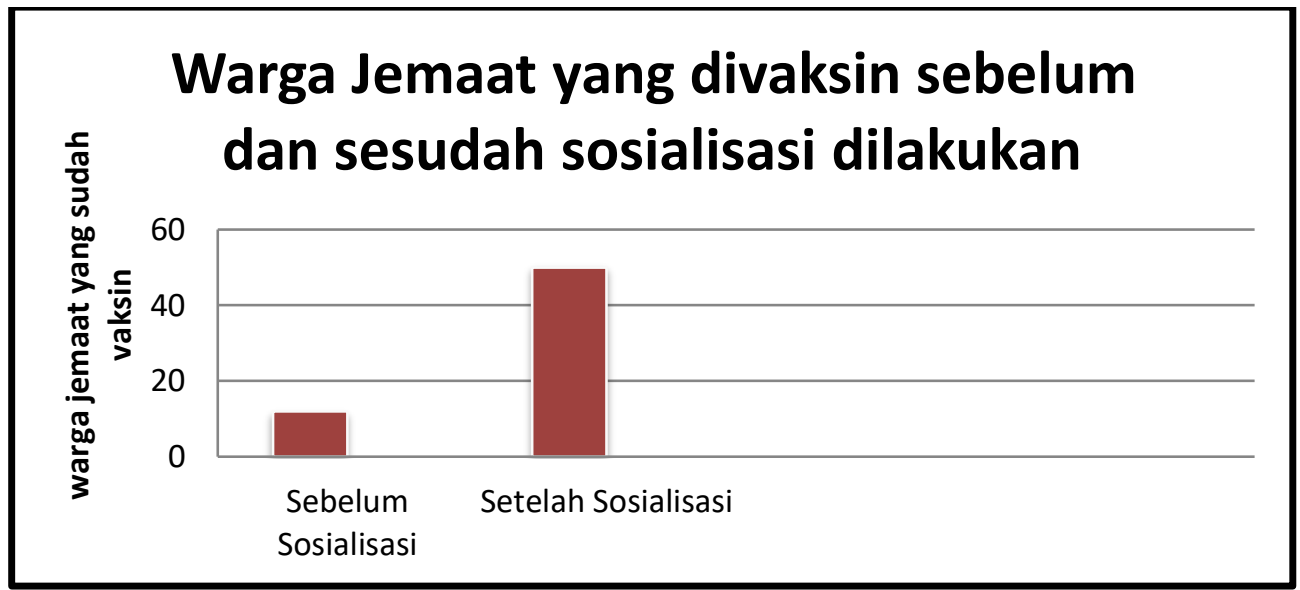

Gambar 6. Chart Keberhasilan Program

\section{2) Pemasangan spanduk Taat Protokol Kesehatan 5M}

Pada tahapan pelaksanaan kegiatan ini, pemasangan spanduk dilakukan di empat titik pelayanan yang sangat minim kesadaran anggota jemaat akan pentingnya prtokol kesehatan. Spanduk ini dibuat atas pengamatan kelompok di lapangan bahwa pada empat titik ini taat akan protokol kesehatan merupakan suatu hal yang sering disepelekan. Kelompok sengaja menggunakan kata "taat" pada spanduk protokol kesehatan untuk pengetahuan tentang pentingnya protokol kesehatan telah diketahui oleh semua orang, tetapi untuk melakukannya sesuai dengan anjuran kesehatan tidak dilakukan dengan baik (Ista/QQ/DDL, 2020; Lumbanrau, 2020).

Pemasangan yang dilakukan oleh kelompok pada empat titik pelayanan yakni di sektor Sumber kasih, sektor Elefantin, sektor Bethania dan sektor Galilea. Hal ini diharapkan agar jemaat dapat menaati protokol kesehatan dengan baik sehingga dapat melindungi diri serta dapat membantu pemerintah dalam memutus rantai penyebaran COVID-19 secara bersama-sama.

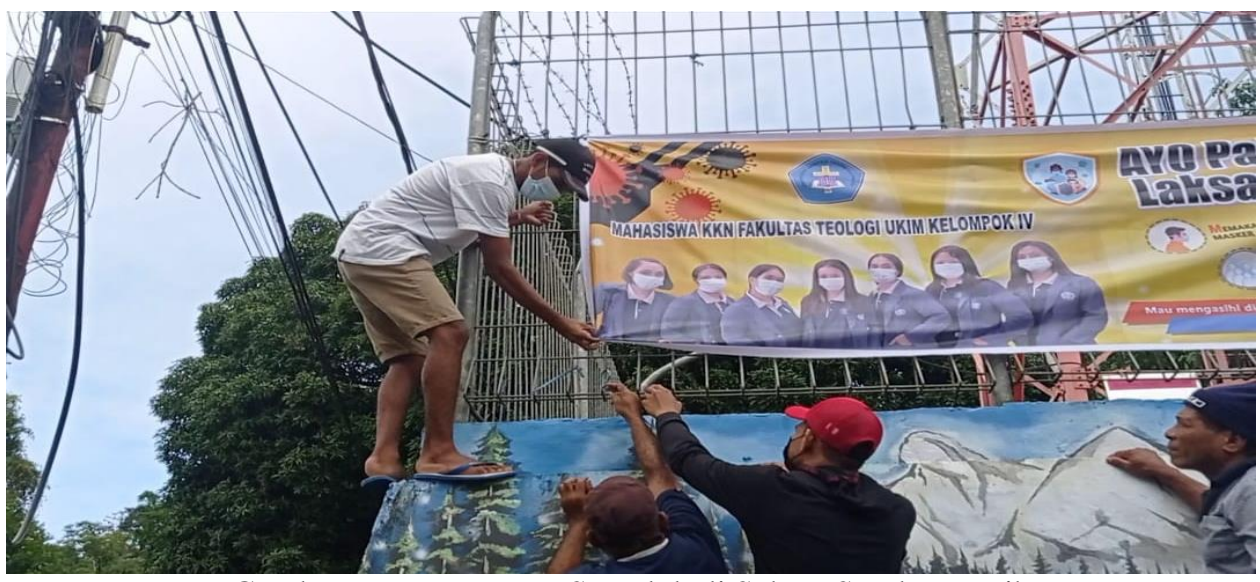

Gambar 7. Pemasangan Spanduk di Sektor Sumber Kasih 


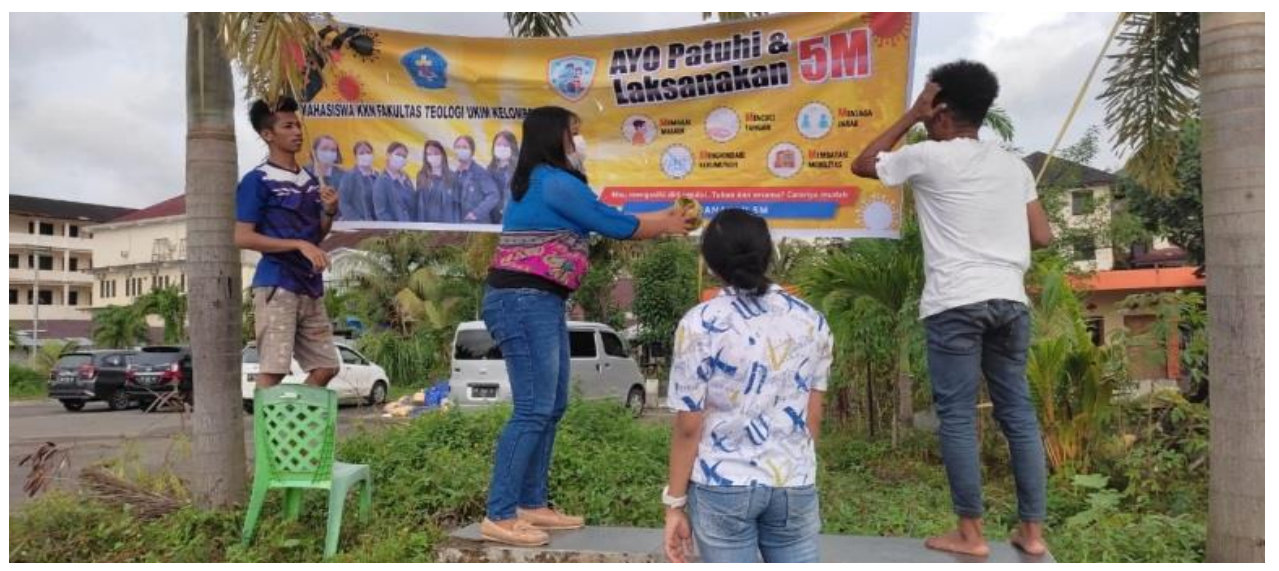

Gambar 8. Pemasangan Spanduk di Sektor Galilea

3) Sosialisasi Vaksin, Taat Protokol Kesehatan dan Deskriminasi Terhadap Anggota Jemaat Yang Terpapar COVID19 Melalui Audio Suara Kasih

Pada tahapan ini kelompok membuat audio suara kasih. Audio yang berdurasi 3 menit ini memuat tentang vaksinasi, taat protokol kesehatan dan tindakan diskriminasi yang tidak boleh dilakukan kepada anggota jemaat yang terpapar COVID-19. Seiring dengan berjalannya situasi sekarang maka tingkat kewaspadaan orang-orang terhadap bahaya COVID-19 sudah menurun. Sehingga lewat sosialisasi ini akan meningkatkan kesadaran anggota jemaat terehadap bahaya COVID-19 sehingga tindakan apa saja yang paling tepat dilakukan dalam melindungi diri sendiri dan orang lain. Warga jemaat kembali diingatkan untuk taat protokol kesehatan dan mengikuti program pemerintah untuk vaksin.

Dalam audio suara kasih juga dibahas tentang tindakan yang paling tepat dilakukan terhadap orang-orang yang terpapar COVID-19. Sering kali terjadi di dalam masyarakat bahwa tindakan yang dilakukan kepada orang-orang yang terpapar COVID-19 yaitu tekanan yang membuat mereka semakin menderita, karena tekanan sosial, sehingga dari suara kasih ini warga jemaat diingatkan untuk saling menguatkan dan mendukung keluara, saudara, tetangga atau teman yang sedang terpapar COVID-19

Sosialisasi audio diputar pada titik-titik pelayanan dengan mengunakan 30 menit sebelum jalannya pelayanan. Untuk pemutaran audio, kelompok bekerja sama dengan kelompok LSPB Jemaat GPM Rehoboth untuk pemutaran audio suara kasih. Sebelum teman-teman LSPB memimpin Kebaktian maka mereka akan meminta Majelis atau pelayan yang ada di titik pelayanan untuk memutar suara audio suara kasih.

\section{4) Sosialisasi Taat Protokol Kesehatan 5M Melalui Video}

Pada tahapan ini sosialisasi dilakukan dengan membuat video kreatif yang memuat tentang edukasi kepada anggota jemaat tentang pentingnya taat protokol kesehatan 5M. Pembuatan audio kelompok bekerja sama dengan seorang editor video sehingga video yang dihasilkan berisi edukasi taat protokol kesehatan dengan animasi bergerak untuk lebih meningkatkan pemahaman anggota jemaat ketika menonton video ini. Video taat Prokes 5M ini kelompok bekerja sama dengan MJ GPM Rehoboth untuk mengupload video pada media sosial atau mengirim pada group-group whatsaap.

\section{Kesimpulan}

Demikian kegiatan pengabdian kepada masyarakat yang telah di lakukan oleh Tim PKM Universitas Kristen Indonesia Maluku (UKIM) Ambon melalui TIM KKN LSPB Fakultas Teologi UKIM, dengan catatan bahwa kegiatan ini akan ditindaklanjuti lewat kegiatan selanjutnya berupa pengiriman artikel ilmiah yang dihasilkan bersama mitra. Sebagai luaran kegiatan ini, video kegiatan telah di upload pada chanel YouTube https://youtu.be/R8i3W9G6INg. Diharapkan kepada pihak-pihak terkait misalnya Majelis Jemaat GPM Rehoboth dan Perguruan Tinggi yang terlibat dapat 
menindaklanjuti kegiatan-kegiatan seperti ini dan kegiatan yang lebih baik lagi kepada mahasiswa-mahasiswa yang lain sebagai upaya yang akan berdampak pada peningkatan kualitas tulisan yang di hasilkan.

\section{References}

Astutik, Y. (2021). Banyak Hoaks Beredar, Jangan Takut Divaksin yah Guys!, Jakarta: CNBC Indonesia. URL: https://www.cnbcindonesia.com/news/20210114105232-4-215861/banyak-hoaks-beredar-jangan-takutdivaksin-yah-guys. Access: 17 August 2021.

Ista/QQ/DDL. (2020). Kepatuhan Masyarakat Terhadap Protokol Kesehatan Harus Ditingkatkan. Jakarta: Tim Komite Penanganan Corona Virus Disease 2019 (COVID-19) dan Pemulihan Ekonomi Nasional. URL: https://COVID19.go.id/p/berita/kepatuhan-masyarakat-terhadap-protokol-kesehatan-harus-ditingkatkan. Access: 17 August 2021.

Kementerian Kesehatan Republik Indonesia. (2021). Frequently Asked Question: Seputar Pelaksanaan Vaksinasi COVID-19, Tersedia pada URL: https://kesmas.kemkes.go.id/assets/uploads/contents/others/FAQ_VAKSINASI_COVID_call_center.pdf , Access: 17 August 2021.

Lumbanrau, R.E. (2020). COVID-19 Indonesia terus naik: "Orang yang tak taan protocol makin banyak" karena "masyarakat menengah bawah tak paham"? Jakarta: BBC News Indonesia. URL: https://www.bbc.com/indonesia/indonesia-53553408. Access: 17 August 2021.

Safrizal, ZA, Putra, D.I., Sofyan, S., \& Bimo. (2020). Pedoman Umum Menghadapi Pandemi COVID-19 Bagi Pemerintah Daerah: Pencegahan, Pengendalian, Diagnosis dan Manajemen. Jakarta: Tim Kerja Kementerian Dalam Negeri untuk Dukungan Gugus Tugas COVID-19. URL: https://infeksiemerging.kemkes.go.id/document/download/3ax61Bxrn5. Access: 17 August 2021.

Sembiring, I.G.N. (2021). Masih Banyak Warga yang Enggan Disuntik Vaksin COVID-19, Apa Alasan Mereka?, Jakarta: Kompas.com. URL: https://megapolitan.kompas.com/read/2021/06/19/16592351/masih-banyakwarga-yang-enggan-disuntik-vaksin-COVID-19-apa-alasan-mereka?page=all. Access: 17 August 2021.

Septiana, T. (2020). Pengertian Vaksin dan Cara Kerjanya Terhadap Tubuh, Jakarta: Kontan. URL: https://kesehatan.kontan.co.id/news/pengertian-vaksin-dan-cara-kerjanya-terhadap-tubuh. Access: 17 August 2021.

Tim Komunikasi Publik - KPCPEN. (2021). Apakah Vaksin COVID-19 adalah Obat?, Jakarta: Kementerian Kesehatan RI. URL: https://COVID19.go.id/edukasi/masyarakat-umum/apakah-vaksin-COVID-19-adalah-obat-1. Access: 17 August 2021.

Tim Renstra. (2021). Rencana Strategis Jemaat GPM Rehoboth 2021-2025, Ambon: Majelis Jemaat Jemaat GPM Rehoboth.

Touwely, G. H., Nanuru, R. F., Laisila, M., \& Dandirwalu, R. (2019). Assistance on Writing Scientific Papers for Students of Nusaniwe Village. Indones. J. Cult. Community Dev., 4(1), 23-31, DOI: 10.21070/ijccd.v2i3.70.

Winastya, K.P. (2021). Tak Percaya Corona \& Vaksin, Jemaat dan Pendeta Puluhan Gereja di Papua Bakar Masker, Jakarta: merdeka.com. URL: https://www.merdeka.com/trending/tak-percaya-corona-amp-vaksin-jemaat-amppendeta-puluhan-gereja-di-papua-bakar-masker.html. Access: 17 August 2021. 